\title{
凹 人工へム酵素の分子設計
}

\section{渡辺 芳人}

1 はじめに

酵素反応の詳細な解析を目的とした biomimetic chemistry が盛んになって早いもので 30 年近くになる。私自身 も，80 年代はじめから鉄ポルフィリン錯体を用いた酸化反 応を行うへム醭素のモデル研究に参加している。モデル系を 用いる最大の長所は, 䤃素系では観測不可能な不安定中間体 の合成・構造決定・反応性の系統的な研究等が可能になるこ とであろう。特に，有機溶媒中の反応は $-80^{\circ} \mathrm{C}$ 程度でも可 能なこともあり，不安定化学種を比較的長寿命で観測できる 場合も結構多いし，色々な置換基の導入による中間体の反応 性の制御も可能となる。ところで，モデル系による研究を通 じて得られる酥素反応に関する結果は, 「本当に蛋白内部で も起こるのであろうか？」というあまりにも素朴で，なおか つ本質的な疑問に対し，充分な答えを与えているであろう か? こうした問題意識の下, 本稿ではモデル系の研究結果 に基づいたへム酵素の分子設計を行った例を紹介させていた だきたい。電子移動過程に関する話題は，あまり出てこない ことを拉許し願いたい。

\section{2 酸化反応に関与するへム酵素}

活性中心に鉄ポルフィリン錯体（へムと呼ぶ）を有する蛋 白質を総称してへム蛋白質と呼ぶ'”。ム蛋白質として代表 的なのはへモグロビンやミオグロビンなどであろう。これら は酸素分子の運搬や賩蔵に関与していることは誰でも知って いることである。この他にも色々な反応を触媒するへム䣲素 が知られている $\left(\right.$ Table 1) ${ }^{2)}$. 私どもが特に興味を持って研 究を行っているへム酵素は, 酸化反応や酸素原子添加反応を 触媒する酵素である．もちろん，ミオグロビンやへモグロビ ンには，こうした酸化反応を触媒する機能はない。このよう に，活性中心は共通のへムで構成されながら，それぞれの蛋 白や酵素が異なる機能を発揮できるのは何故であろうか？へ 厶周辺を構成するアミノ酸が異なるというのが大きな理由の 一つであろう．さらに，細かく見ていくと，へム鉄に配位し ている軸配位子が，ヒスチジン・システイン・チロシンと三

Table 1 Versatile biological functions of hemoproteins.

\begin{tabular}{cc}
\hline $\mathrm{O}_{2}$ transportation & hemoglobin, myoglobin \\
respiratory chain & cytochrome oxidase \\
monooxygenation & cytochrome P-450 \\
$\mathrm{H}_{2} \mathrm{O}_{2}$ activation & peroxidase \\
$\mathrm{H}_{2} \mathrm{O}_{2}$ dismutation & catalase \\
$\mathrm{NO}$ synthesis & $\mathrm{NO}$ synthase \\
$\mathrm{NO}$ reduction & $\mathrm{P}-450$ NOR \\
heme metabolism & (heme oxygenase)
\end{tabular}

種類あり ${ }^{3,4)}$ ，軸配位子の違いも酵素の反応性に反映される ものと考えられる. 周辺アミノ酸や軸配位子の効果を検証す るために一般的に用いられる手法は, 特定アミノ酸の部位特 異的な置き換え（ミューテーション）である. 機能的に重要 と思われるアミノ酸を他のアミノ酸に置き換えることで反応 性が低くなるなどの現象から，そのアミノ酸の役割を検討す ることが出来る。これに対し我々の戦略は，機能をなくすこ とで特定アミノ酸の効果を評価するだけではなくて, 蛋白に 特定の機能を賦与するようなアミノ酸置換を行う事にある. もち万ん，やみくもにアミノ酸を入れ替えるのではなくて， 特定の化学反応の反応機構を吟味し, その反応を進行しやす くする周辺環境を設計するのである.

\section{1 ペルオキシダーゼ反応}

ペルオキシダーゼは, 過酸化水素と反応して compound I と呼ばれる $\mathrm{O}=\mathrm{Fe}(\mathrm{IV})$ ポルフィリン $\pi$ カオンラジカル $\left(\mathrm{O}=\mathrm{Fe}^{\mathrm{NV}} \mathrm{Por}^{+} \bullet\right)$ を酸化活性種として生成する4). 反前の 状態 (resting state と呼ぶ) は Fe ${ }^{\mathrm{III}}$ Por なので, 中心金属で ある鉄と配位子であるポルフィリンがそれぞれ一電子酸化さ れ，全体で二電子分の酸化当量を持っていることになる. compound I は外来基質の一電子酸化を二度繰り返し resting stateに戻る. 最初の一電子酸化により compound Iは $\mathrm{O}=\mathrm{Fe}^{\mathrm{IV}}$ Por (compound II と呼ばれている) へと還元され， 鉄上に残っている一電子酸化当量を使って二回目の酸化反応 を行うことになる.これらをまとめたのが Scheme 1 である. 過酸化水素とペルオキシダーゼの反応による compound I の生成速度は $10^{7} \mathrm{~s}^{-1} \mathrm{M}^{-1}$ 前後であり4), 驚くほど速い反応 である．反応を速やかに進めるためにはそれなりの仕掛が必 要となるが, cytochrome $c$ peroxidase $(\mathrm{C} c \mathrm{P})$ の場合を例 にとって，その仕組みを紹介したい (Scheme 2) ${ }^{5}$ ). 過酸化 水素が $\mathrm{C} c \mathrm{P}$ の反応場に入ってくると，隣接しているヒスチ ジン（His 52）が塩基として作用し, 過酸化水素のプロトン 引き抜きによる $\mathrm{Fe}(\mathrm{III})-\mathrm{O}-\mathrm{OH}$ 種の生成を助ける。ヒスチ ジンに付加しているプロトンは $\mathrm{Fe}$ (III)-O-OHに酸として 作用し， O-O 結合のイオン的解裂による $\mathrm{H}_{2} \mathrm{O}$ の生成を助け,

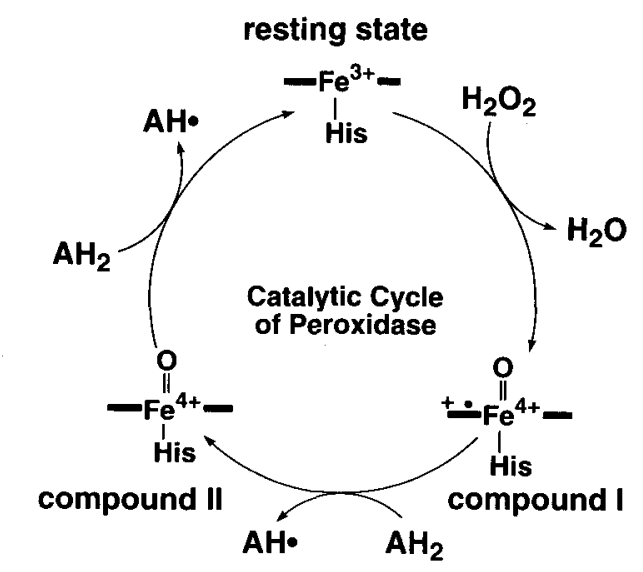

Scheme 1 Catalytic reaction cycle of peroxidase reactions. 

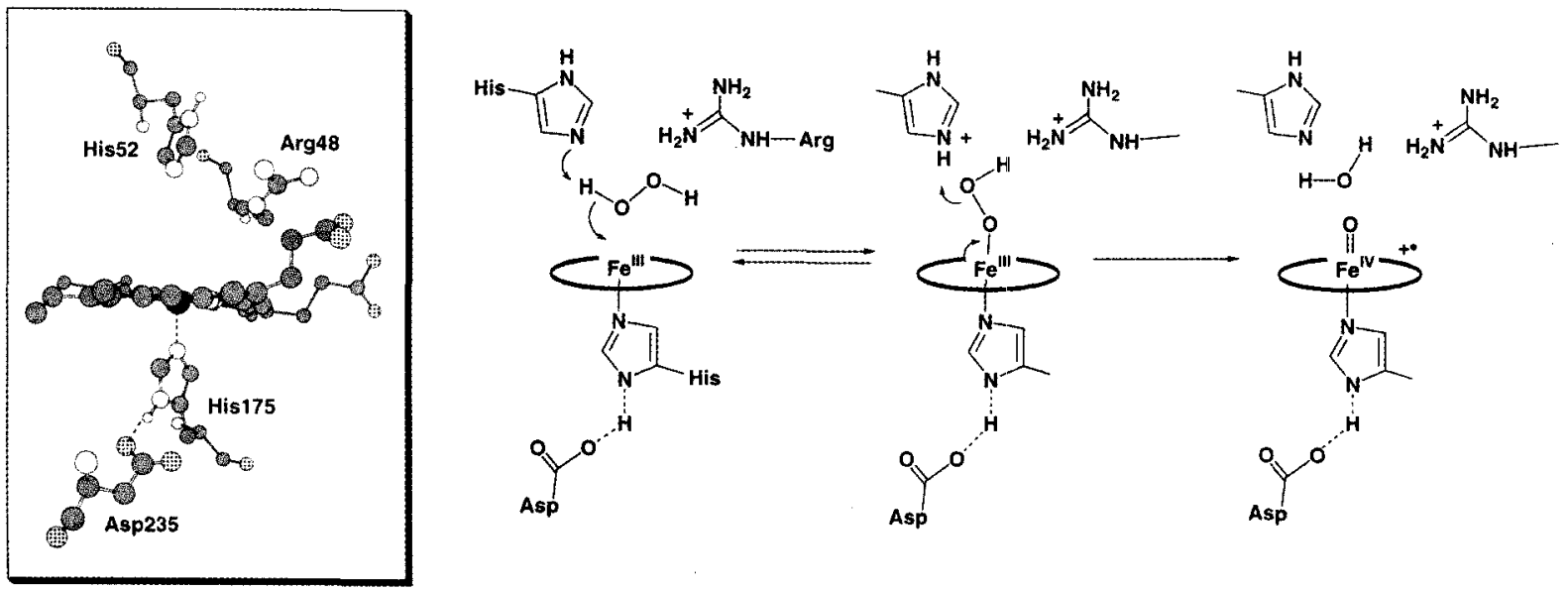

Scheme 2 An active site structure of cytochrome $c$ peroxidase $(\mathrm{C} c \mathrm{P})$ and functional roles of amino acid residues around heme.

同時に compound I $\left(\mathrm{O}=\mathrm{Fe}^{\mathrm{IV}} \mathrm{Por}^{+} \bullet\right)$ が生成する. 生理的 条件下ではプロトン化しているアルギニン（Arg 48）が近傍 に存在する事で反応系をより極性に保ち，全てがイオン的な 化学反応過程である上記の反応の進行を助けている。ささらに, $\mathrm{O}-\mathrm{O}$ 結合のイオン的な解裂は，アニオン性軸配位子である ヒスチジン（His 175）によっても加速されると考えられ， こうした複合的な仕掛の結果として compound I が効率よ く生成するものと理解される。

compound I 生成のために周辺アミノ酸がいかに重要かを 見てきたが，これはあくまでも合理的な推論であって，仮説 の域を出るものではない，醅素系に打ける最大の問題点は， $\mathrm{Fe}-\mathrm{O}-\mathrm{OH}$ という最も重要な中間体が観測されないことにあ る。そこで, 我々は，合成モデル系による研究を行い，その 詳細を検討した。

\section{2 ペルオキシダーゼ反応のモデル研究}

86 年に我々が見出したのは，二量体の形成が出来ない程
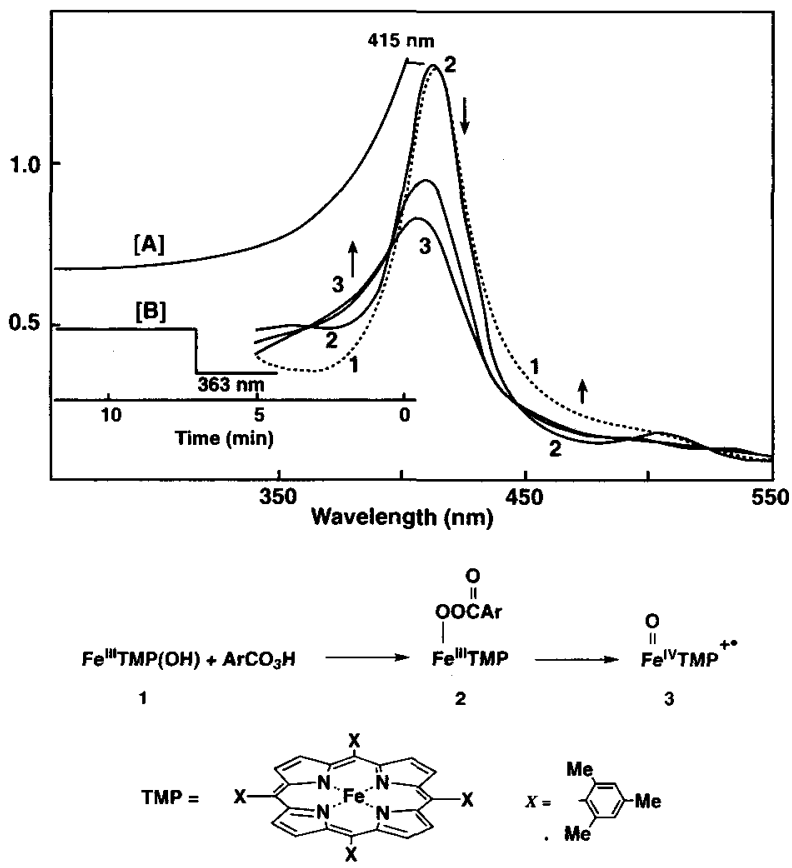

Scheme 3 UV-Vis spectral changes in the reaction of $\mathrm{Fe}^{\mathrm{III}} \mathrm{TMP}(\mathrm{OH})$ with $m \mathrm{CPBA}$ in $\mathrm{CH}_{2} \mathrm{Cl}_{2}$ at $c a .-40^{\circ} \mathrm{C}$.
度に立体的に修飾した鉄ポルフィリン錯体, $\mathrm{Fe} \mathrm{F}^{\mathrm{II}} \mathrm{TMP}$ $(\mathrm{OH})$ と過安息香酸の反応を $-50^{\circ} \mathrm{C}$ 程度の低温下, $\mathrm{CH}_{2} \mathrm{Cl}_{2}$ 中で進行させると，鉄一過酸付加体の生成とそれに引き続く $\mathrm{O}-\mathrm{O}$ 結合のイオン的解裂による $\mathrm{O}=\mathrm{Fe}^{\mathrm{IV}} \mathrm{TMP}^{+}$の生成を吸 収スペクトル変化として直接観測することが出来ることであ った $\left(\right.$ Scheme 3) 6). 中間体である $\mathrm{Fe}^{\mathrm{IIIT}} \mathrm{TMP}\left(\mathrm{ArCO}_{3}\right)$ が 観測されたことから，その後の $\mathrm{O}-\mathrm{O}$ 結合に対する酸触媒・ ポルフィリン環からの電子的効果・第 6 軸配位子の効果なと を検討した。その結果, $\mathrm{O}=\mathrm{Fe}^{\mathrm{IV}} \mathrm{TMP}^{+}$の生成反灾は酸に よって触媒され，ポルフィリン環や第 6 軸配位子から電子供 与することで加速されることが明かとなった ${ }^{7}$. 酸塩基触媒 の重要性と，O-O 結合解裂の遷移状態が Fig. 1 の様になっ ていることがこの研究から明かとなった．また，溶媒を非極 性のベンゼンやトルエンに変えると， $\mathrm{O}-\mathrm{O}$ 結合の解裂がラ ジカル解裂へと変化することが分かった ${ }^{8}$. 䤉素の反応部位 が極性に保たれている意味がモデル系でも示されたと言える.

このように，䤏素の中で進行していると考えられる化学反 応がモデル系の研究から明確に示されたことの意義は大きい と考える。

\section{3 モデル系から人エへム酵素の設計へ}

\section{1 遠位ヒスチジンーアスパラギン間の水素結合}

ミオグロビンと $\mathrm{C} c \mathrm{P}$ のへム近傍の構造を比較すると, Fig. 2aに示すようにいくつかの類似点があることに気がつ く．本稿のはじめに指摘したように，一般酸塩基触媒として 重要な遠位ヒスチジンがどちらの蛋白・醅素にも存在してい る.さらに，へム鉄に配位している第 5 軸配位子も，どちら の場合にもヒスチジンとなっている．従って，ミオグロビン と $\mathrm{C} c \mathrm{P}$ 活性部位は非常に良く似た構造と言うことが出来る. これだけ構造が似ているにも関わらず，ミオグロビンと $\mathrm{C} c \mathrm{P}$ はそれぞれ，相手の機能を発現することはできないの

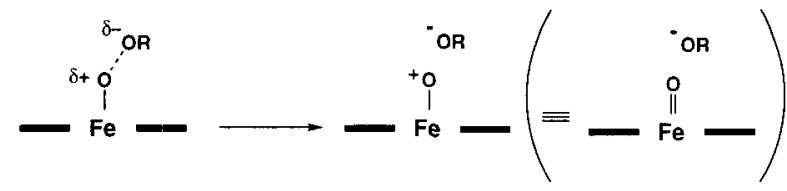

Fig. 1 An expected transition state for the heterolytic O-O bond cleavage. 
である.そこでこの両者の構造をさらに詳細に比較検討して みた。

Fig. 2 b は，ミオグロビンと $\mathrm{C} c \mathrm{P}$ を重称合わせた図であ る．遠位ヒスチジンの鉄からの相対的な位置に大きな違いが 見られる。それと同時に， $\mathrm{C} c \mathrm{P}$ の遠位ヒスチジンは，近傍 のアスパラギン (Asp82) と水素結合を形成している。この 水素結合により，遠位ヒスチジンはアニオン性を帯びてくる。 従って, Scheme 4 に示すように, 過酸化水素からのプロト ンの引き抜き及び，鉄に配位した過酸化水素が水として脱離 する際のプロトン供給が容易に進行することになる。この考 えを実証するために，西洋ワサビペルオキシダーゼ（HRP） を使って，水素結合を削除した，すなわちAsn $\rightarrow$ すシン (Leu）の置換を行ったミュータントを合成した ${ }^{9,10)}$.この ミューテーションにより, compound I の生成速度が $1 / 30$ 程度に滅少したことから, 遠位ヒスチジンの塩基性が酸化活 性種生成に重要な役割を担っていることが分かったここで 得られた HRP のミュータントは，外来基質の一電子酸化反 応では本来の酵素よりも高い酸化活性を示したにも関わらず， フェノールの酸化 $(\mathrm{PhOH} \rightarrow \mathrm{PhO})$ に対して極端に遅い反 応速度を示した。こうした結果から，フェノールの酸化反応 は遠位ヒスチジンによるプロトン引き抜きが最初に進行し，

一電子酸化反応がそれに続くことが実験的に初めて示された.

\section{4 遠位ヒスチジンーへム鉄間距離の重要性}

さて, $\mathrm{C} c \mathrm{P}$ の遠位ヒスチジンの位置が, ミオグロビンに 比べて鉄から遠いということはどれほど重要な意味を持つの であろうか？Fig.1で示したように，O-O 結合がイオン 的に解裂するためには，脱離する側の酸素上にはマイナスチ ヤージが貯まっているはずである， C c P の遠位ヒスチジン のプロトンは, このマイナスチャージを持った酸素原子と選 択的に相互作用できる位置にあることが考えられる。これに 対し，ミオグロビンの遠位ヒスチジンプロトンは，両方の酸 素と相互作用が可能な位置にいるために，O-O 結合のイオ ン的な解裂の遷移状態を安定化させることが出来ないことに

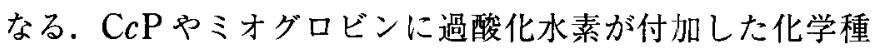
の構造など分かっているわけではないが，酸素分子が還元 $\left(\mathrm{Fe}^{\mathrm{II}}\right)$ 状態の $\mathrm{C} c \mathrm{P}^{\mathrm{II}}$ やミオグロビン12)に配位したオキシ体 の結晶構造が既に報告されている (Fig. 3). 明らかに，遠位 ヒスチジンの位置によって, 酸素との相互作用可能な部位に

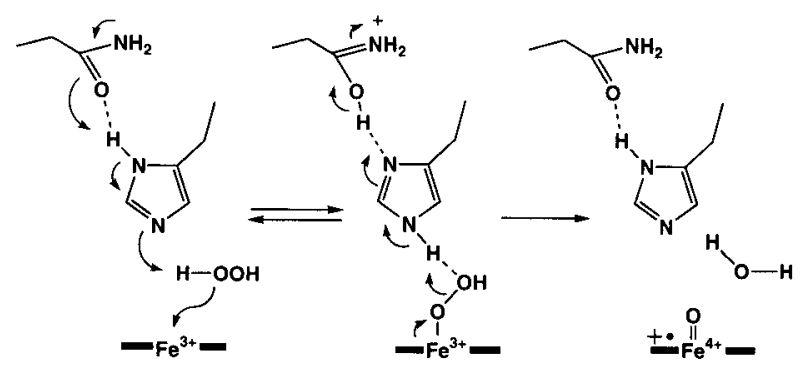

Scheme 4 Possible roles of the Asn-His hydrogen bond for the formation of compound I.
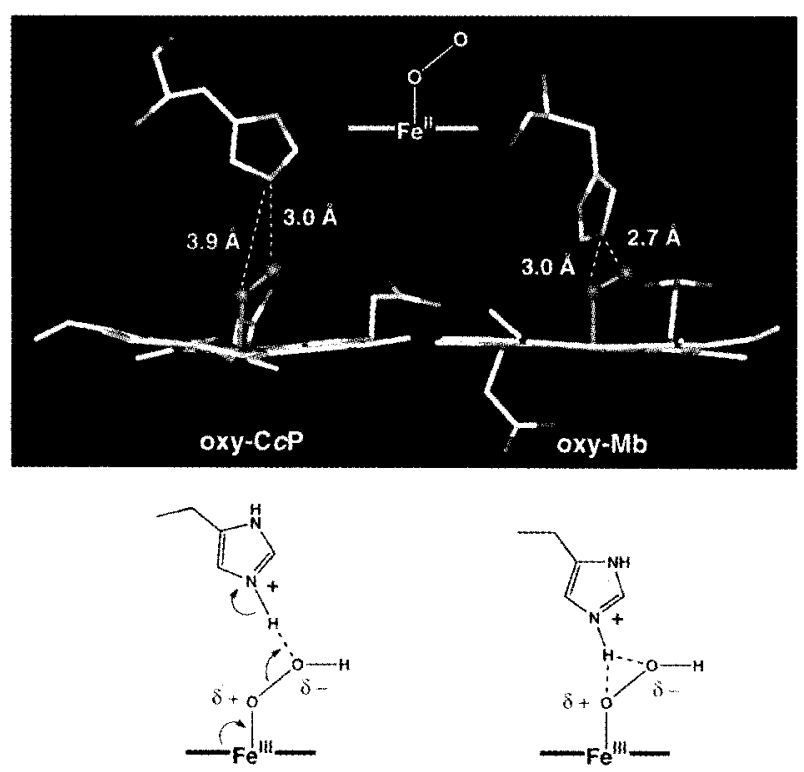

Fig. 3 Oxy-forms of $\mathrm{C} c \mathrm{P}$ and myoglobin determined by their crystal structures.

変化が見られる.そこで，ミオグロビンの遠位ヒスチジンの 位置を $\mathrm{C} c \mathrm{P}$ のような場所に動かして，ミオグロビンにペル オキシダーゼ機能を導入する試みを行った。

\section{1 ミオグロビンへのペルオキシゲナーゼ機能賦与}

ミオグロビンのへム鉄近辺のアミノ酸を検討した結果, 29 番目のアミノ酸であるロイシン (Leu 29) と 43 番目のフェ ニルアラニン (Phe 43) の位置にヒスチジンを導入すると,

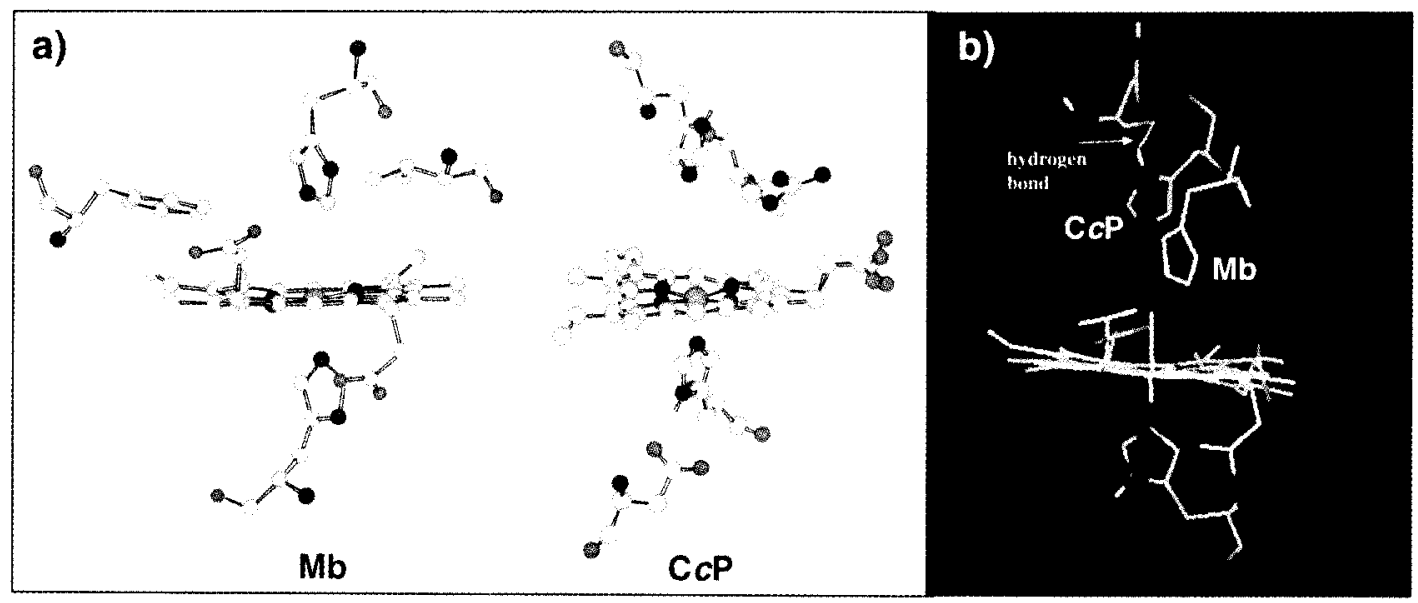

Fig. 2 a) Comparison of active site structures of myoglobin and $\mathrm{C} c \mathrm{P}, \mathrm{b}$ ) Superimposed structures of myoglobin and $\mathrm{C} c \mathrm{P}$. 


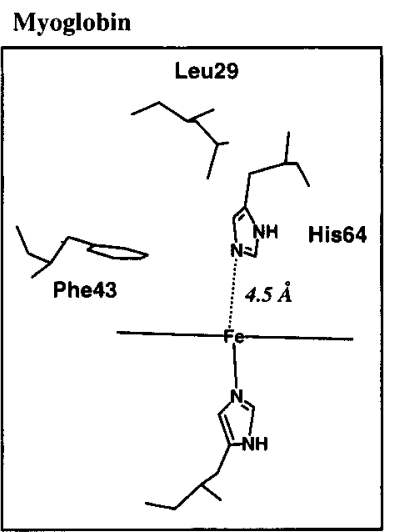

H64L/L29H Mb

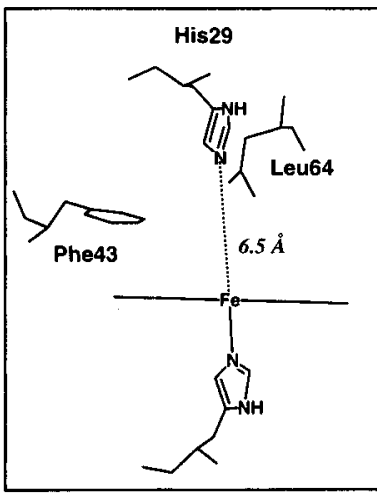

H64L/F43H Mb

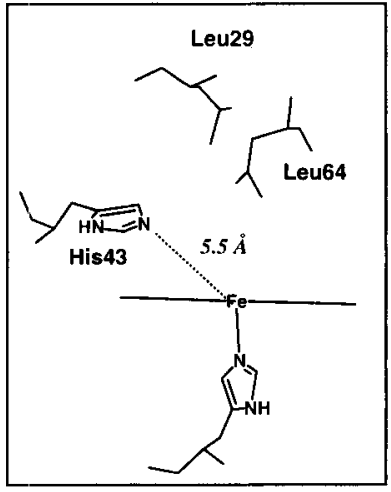

Fig. 4 Crystal structures of wild type, H64L/L29H and H64L/F43H Mb.

鉄一ヒスチジン間の距離がペルオキシダーゼやカタラーゼの 場合に近くなる事が分かり，それぞれの位置にヒスチジンの 導入を行った：その際，遠位ヒスチジン（His 64）は不要な ので，それぞれのミュータントではロイシンへの置き換えを 行っている。っまり，それぞれのミュータントではヒスチジ ンの位置を動かし, 本来ヒスチジンがあった場所にはロイシ ンを導入したダブルミュータント 2 種類 $(\mathrm{H} 64 \mathrm{~L} / \mathrm{L} 29 \mathrm{H}, \mathrm{H}$ $64 \mathrm{~L} / \mathrm{F} 43 \mathrm{H})$ を作成した ${ }^{13)}$. それぞれの構造はX 線による結 晶構造解析により，ヒスチジン一鉄間距離が $6.5 \AA$ ， $5.5 \AA$ と 分かった (Fig.4) ${ }^{14)}$ 。なお, $\mathrm{C} c \mathrm{P} て ゙ は, ~ 5.6 ~ \mathrm{~A}^{15)}$ であり, $\mathrm{H}$

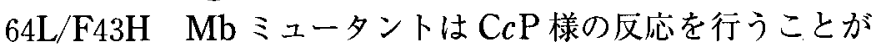
期待された.

得られたダブルミュータントおよびミオグロビンによるス ルフィドとオレフィンの酸化反応を検討した結果を Table 2 にまとめた。なお，ここでは18一酸素で標識した過酸化水素 $\left(\mathrm{H}_{2}{ }^{18} \mathrm{O}_{2}\right)$ が酸化剂として用いられている ${ }^{13,16)}$. 一般的に, スルフィドはオレフィンに比べて酸化しやすい化学種である が，ミオグロビンミュータントの場合にも同じ結果が得られ ている. 少し詳しく結果を見ていくと, スルフィドの酸化に よるスルフォキシドの生成では，ミオグロビン自身でも進行 することが分かる. 生成物に含まれる 18一酸素の割合から， この反応がオキソトランスファーで進行していることは明か である。一方, ヒスチジン一鉄間距離が $6.5 \AA$ とちょっと遠 すぎた $\mathrm{H} 64 \mathrm{~L} / \mathrm{L} 29 \mathrm{H} \mathrm{Mb}$ は，本来のミオグロビンに比して 40 倍の反応性を示し, 驚くべき事には，97\%という高い光学 選択性が現れたことである。沶手本とした $\mathrm{CcP}$ と同様に， ヒスチジンー鉄間距離が $5.5 \AA$ đ゙あった $\mathrm{H} 64 \mathrm{~L} / \mathrm{F} 43 \mathrm{H} \mathrm{Mb}$ 至っては，400倍近い酸化活性の向上が見られ，光学選択性 も $85 \%$ と高い值が得られている. 本来ヒスチジンが存在し ていた位置に大きさが小さいロイシンを導入したことにより， 外来基質のための結合ポケットが出来 (Fig.4 参照) ${ }^{17)}$, こ うした高い光学選択性が現れたものと解釈している.

スルフィドよりも酸化反応が進行し難いオレフィンのエポ キシ化反応の場合を見てみよう．ミオグロビン自身でも多少 の反応は進むものの, 用いた過酸化水素由来の酸素がほとん ど生成物に導入されていないことは明かである. 従って，こ の反応では，へム酵素が行っているオキソトランスファー型 の反応は進行していないことが示されている，これまでの研 究結果から，ミオグロビンによるエポキシ化反応は, 蛋白表 面に生成したチロシンラジカルと酸素分子が関与しているこ
Table 2 Sulfoxidation and epoxidation by myoglobin and its mutants.

\begin{tabular}{|c|c|c|c|}
\hline Protein & $\begin{array}{l}\text { Turn over } \\
\text { (/min) }\end{array}$ & $\mathrm{H}_{2}{ }^{18} \mathrm{O}_{2}$ & e.e. $(\mathrm{R})$ \\
\hline \multicolumn{4}{|c|}{$\mathrm{Ph}-\mathrm{S}-\mathrm{Me} \longrightarrow \mathrm{Ph}-\mathrm{S}-\mathrm{Me}$} \\
\hline $\begin{array}{l}\text { Sperm Whale } \\
\text { Myoglobin }\end{array}$ & 0.13 & 92 & 25 \\
\hline $\mathrm{L} 29 \mathrm{H} / \mathrm{H} 64 \mathrm{~L}$ & 5.5 & 97 & 97 \\
\hline F43H/H64L & 47 & 96 & 85 \\
\hline \multicolumn{4}{|c|}{ 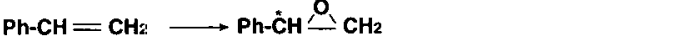 } \\
\hline $\begin{array}{l}\text { Sperm Whate } \\
\text { Myoglobin }\end{array}$ & 0.015 & 20 & $9 R$ \\
\hline F43H/H641. & 4.5 & 94 & $68 R$ \\
\hline L29H/H64I. & 0.14 & 94 & $80 R$ \\
\hline
\end{tabular}

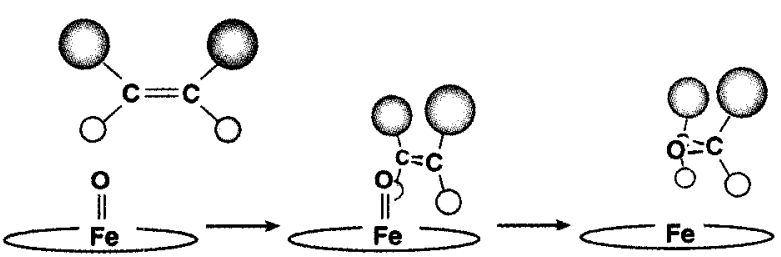

Scheme 5 Epoxidation by synthetic models of compound I proceeds with cis selectivity.

とが指摘されているが18), 我々の結果も同様のことを示して いる.これに対し, 二つのミュータントでは, エポキシドに 過酸化水素由来の酸素が導入されており, 高い光学選択性が 堅持されている. 反応活性もミオグロビンに対して 10〜300 倍となっており，遠位ヒスチジンの位置の変換によってミオ グロビンに刘して酸化酵素機能を導入することが出来たと結 論される。

反応部位が蛋白内に用意されることで，有機溶媒中の均一 系の反応とは異なる選択性が得られることがある．例えば， 合成鉄ポルフィリン錯体によるエポキシ化反応では，シスー オレフィンがトランスーオレフィンに比べてはるかに高い反 応性を示す.これは, Scheme 5 に示すようなオレフィンと 酸化活性種との相互作用によって反応が進行することによる と考えらている.これに対し，我々の制作したミュータント の場合には，トランスーオレフィンの方が高い反応性を示す 事が示された ${ }^{19)}$. 従って, 蛋白質内部における基質結合部位 
の構造が選択制に大きく寄与していることが分かる。

\section{2 酸化活性種の直接観測}

ここまで紹介してきたミュータントの設計では，へム鉄に 過酸化水素が配位し， O-O 結合がイオン的に解裂するため には，遠位ヒスチジンが遷移状態（Fig. 1）を安定化するこ とが可能な位置に存在する必要がある事を強調し，そのため のミューテーションを行った。こうした操作により, 酸化活 性種である compound I の生成速度が大幅に向上している ことが期待される。実際，H64L/F43H Mbでは，ミオグロ ビンと比ベて二桁高い酸化活性が観測されている.

一力, Table 2 に示したスルフィド及びオレフィンの酸化 反応を見ると, ミオグロビンの場合, 反応性の高いスルフィ ドに対してはオキソトランスファー型の酸化反応が進行して いる.この結果から，活性は低いもののミオグロビンでも酸 化活性種である compound Iが生成していることが伺われ る.これに対して，反応性の低いオレフィンではオキソトラ ンスファー型の反岕がほとんど進行していないことが示され た。従って，一旦生成した活性種がオレフィンと反応するよ りも速く蛋白自身を酸化してしまい，最終的に蛋白表面にチ ロシンラジカルを与える事により ${ }^{18)}$ ，酸素分子を含む化学種 によりエポキシ化が進むと考える事が出来る。これに対し， ミュータントではオレフィンの酸化反応でも18一酸素の生成 物への導入が $94 \%$ 以上で進行している. 従って, ヒスチジ ンの位置をミオグロビンに比して1〜2 A遠く八移したこと により，酸化活性種による蛋白の酸化を防いでいるという事 が考えられる．既に述べたように，今回のミューテーション は, compound I の生成速度を上げるように設計しているが, さらに，生成した compound I が周辺アミノ酸を酸化する ことなく安定に存在するとすれば, 活性種である compound I が観測できる可能性が出てくる，そこで，活性種の 直接観測を試みることにした。

Fig. 5aは，ミオグロビンとメタクロロ過安息香酸 $(m \mathrm{CPBA})$ の反応をストップトフローで追跡した結果であ る ${ }^{16)}$ 。この変化は, $\mathrm{Fe}(\mathrm{III})$ が $\mathrm{O}=\mathrm{Fe}(\mathrm{IV})$ へと変換される 過程である.同様の反応をペルオキシダーゼで行えば $\mathrm{O}=$ $\mathrm{Fe}$ (IV) Por $^{+}$(compound I) が生成するのと杜椂子がずい ぶん異なる。 ミオグロビンと同じ条件下で我々の作成したミ ユータント $(\mathrm{H} 64 \mathrm{~L} / \mathrm{F} 43 \mathrm{H})$ と $m$ CPBA の反応を検討したの がFig. 5 b である ${ }^{16)}$. 反応初期の $40 \mathrm{~m}$ 秒で中間体が一旦生 成し，最終的にミオグロビンの反応でも観測された $\mathrm{O}=\mathrm{Fe}$ (IV) へと変化していく過程が観測されている。初期に生成 する中間体のスペクトルは西洋ワサビペルオキシダーゼ (HRP) の compound I ${ }^{14,20)}$ に酷似している。最終的に は，40 $\mathrm{m}$ 秒後に生成した中間体と基質であるスルフィドや オレフィンとの反㐫をストップトフローで追跡し，この中間 体が酸化活性種であることを確認した。この一連の研究によ って，ミオグロビンの compound Iの初めての観測にミュ ータントを用いて成功したことになる。

\section{5 おわりに}

駆け足で，最近我々が行った人工的なへム䣼素の作製に関 する研究を紹介した21). 我々のミュータントが行う酸化（酸 素添加）反応を中心に話を進めたが，アミン類のように一電 子酸化されやすい化学種に対しては, 高い一電子酸化活性 (ペルオキシダーゼ活性)を示す．現在は，へム酵素が触媒
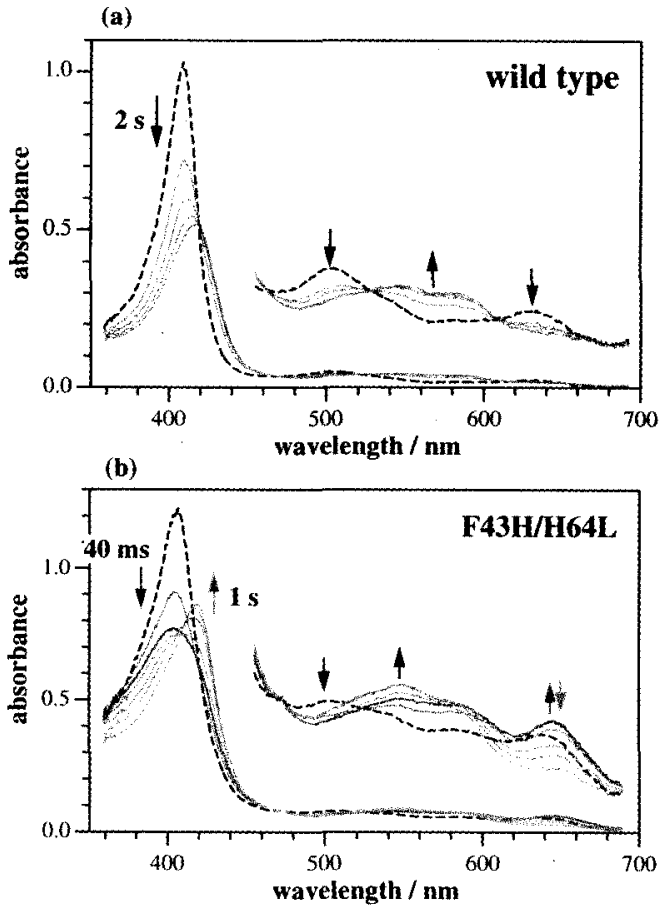

Fig. 5 Reactions of myoglobin (a) and $\mathrm{F} 43 \mathrm{H} / \mathrm{H} 64 \mathrm{~L} \mathrm{Mb}$ (b) with $m$ CPBA.

する様々な酸化反応を，この研究で作成した一連のミオグロ ビンミュータントで再現できるか検討している最中である. それと同時に，高い光学選択性が得られているが，単に「ミ ユータントの基質結合部位が不斉だから，生成物にも不斉が 導入された」という解説では，化学者を納得させることは出 来ない，今回の例では，生成物全てが $\mathrm{R}$ 体として得られた が，積極的に S 体を得るための反応場の設計（ミューテー ション）が出来ないものかと現在思案中である.

\section{文 献}

1) 亘 弘，生越久靖，飯塚鉄太郎 編，ヘムタンパク質の 化学, 化学增刊 76 (1978).

2) E. Ochiai, Bioinorganic Chemistry: An Introduction, Alleyn and bacon, Inc., Boston, Capters 5-7 (1977).

3) T. L. Poulos, The Porphyrin handbook, (Eds. K. M. Kadish, K. M. Smith, and R. Guilard) Academic Press, San Diego, Vol. 4, 189 (2000).

4) H. B. Dunford, Heme Peroxidases., Wiley-VCH, New York (1999).

5) J. H. Dawson, Science, 240, 433 (1988).

6) J. T. Groves and Y. Watanabe, J. Am. Chem. Soc., 108, 7834 (1986); 110, 8443 (1988)

7) K. Yamaguchi, Y. Watanabe, and I. Morishima, J. Am. Chem. Soc., 115, 4058 (1993).

8) J. T. Groves and Y. Watanabe, J. Am. Chem. Soc., 108, 7836 (1986).

9) S. Nagano, M. Tanaka, K. Ishimori, Y. Watanabe, and I. Morishima, Biochemistry, 35, 14251 (1996).

10) M. Mukai, S. Nagano, M. Tanaka, K. Ishimori, I. Morishima, T. Ogura, Y. Watanabe, and T. Kitagawa, J. Am. Chem. Soc., 119, 1758 (1997).

11) S. E. Phillips, J. Mol. Biol., 142, 531 (1980).

12) M. A. Miller, A. Shaw, and J. Kraut, Nature. Struct. Biol., 1, 17880 (1988). 
13) S. Ozaki, T. Matsui, and Y. Watanabe, J. Am. Chem. Soc., 118, 9784 (1996).

14) T. Matsui, S. Ozaki, E. Liong, G. N. Phillips, and Y. Watanabe, J. Biol. Chem., 273, 2838 (1999).

15) B. C. Finzel, T. L. Poulos, and J. Kraut, J. Biol. Chem., 259, 13027 (1984).

16) S. Ozaki, T. Matsui, and Y. Watanabe, J. Am. Chem. Soc., 119, 6666 (1997).

17) The structure was calculated by Insight II/Discover ver. 3.0 (1995)

18) P. R. Ortiz de Montellano and C. E. Catalano, J. Biol. Chem., 260, 9265 (1985).

19) S. Ozaki, H.-J. Yang, T. Matsu, Y. Goto, and Y. Watanabe, Tetrahedron: Asymmetry, 10, 183 (1999).
20) D. Dolphin, A. Forman, D. C. Borg, J. Fajer, and R. H Felton, Proc. Natl. Acad. Sci. U.S.A., 68, 614 (1971).

21) S. Ozaki, T. Matsui, M. P. Roach, and Y. Watanabe, Coord. Chem. Rev. 198, 39 (2000).

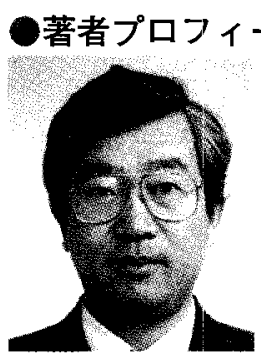

氏名：渡辺 芳人 Yoshihito WATANABE

所属: 分子科学研究所 - 総合研究大学院大学 （T444-8585 岡崎市明大寺町字西郷中 38)

役膱：教授

趣味：スキー，ソフトボール，マックによる 打絵書

\section{5 金属錯体による $\mathrm{CO}_{2}$ の 電気化学的活性化}

\section{田中 晃二}

金属錯体上で活性化した二酸化炭素の反応性としては炭素 一酸素結合開裂を経て有機化合物に還元する反応系と $\mathrm{CO}_{2}$ 骨 格を有機化合物に固定する反応系に大別される，金属上での 活性化では還元反応が優先的に起こり，配位子上での活性化 は固定反応に適するようである。また，特殊な反応例として 架橋イオウと金属上で還元的に活性化した 2 分子の $\mathrm{CO}_{2}$ の カップリング反応によるシュウ酸生成を概略する.

\section{1 はじめに}

これからの科学では環境・エネルギー・資源が極めて重要 な研究課題になることは疑問の余地がないように思われる. 反応が自発的に進行するためには反応基質に比べて生成物が 熱力学的に有利であることが必要条件である。一方，外部か らエネルギーを注入しないと進行しないような熱力学的に不 利な物質変換は経済的理由から無視され続けられてきた。し かしながら，人類の生産活動が余りにも膨大となり，熱機関 から排出される二酸化炭素はもはや自然界が処理しうる量を 遙かに凌駕している，そのため，我々は否応なしに熱力学的 に有利とはいえない二酸化炭素の再資源化に携わることが要 求されている ${ }^{1)}$.これまでに，低原子価の $\mathrm{Ni}, \mathrm{Pd}, \mathrm{Rh}$ 錯体 触媒存在下で, $\mathrm{CO}_{2}$ をエポキシド，ジェン，アルキン等の 活性な不飽和有機化合物と反応させてプロピレンカーボネイ ト，ラクトンおよび $\alpha$-ピロン等の環状化合物を触媒的に合 成する反応は報告されている ${ }^{2)}$ （しかしながら， $\mathrm{CO}_{2}$ と自発 的に反応子る有機基質は極めて限定されており, 通常, $\mathrm{CO}_{2}$ を有機化合物に還元あるいは固定するには，有機基あるいは $\mathrm{CO}_{2}$ を活性化させることが必要である.したがって，二酸 化炭素の資源化はエネルギー問題そのものであり，出来るた け小さな消費エネルギーで $\mathrm{CO}_{2}$ を有機物に変換しうる反応 系の開発が重要である. 本稿では金属錯体の中心金属とイオ ウ配位子上で活性化した $\mathrm{CO}_{2}$ の反応性に関して述べる。

\section{2 二酸化炭素還元の熱力学}

二酸化炭素還元反応（1-6 式）の特色は多電子還元が進 行する程, 平衡電位 ( $E$ vs. SCE, pH 7.0) が正側にシフト することである. したがって，熱力学的には $\mathrm{CO}_{2}$ 還元は多 電子還元を行う方が消費されるエネルギーは少なくなる3．

$$
\begin{array}{ll}
\mathrm{CO}_{2}+\mathrm{e}^{-} \rightarrow \mathrm{CO}_{2} & \text { (1) } E^{0}=-2.14 \mathrm{~V} \\
\mathrm{CO}_{2}+2 \mathrm{e}^{-}+2 \mathrm{H}^{+} \rightarrow \mathrm{HCOOH} & \text { (2) } E^{0}=-0.85 \mathrm{~V} \\
\mathrm{CO}_{2}+2 \mathrm{e}^{-}+2 \mathrm{H}^{+} \rightarrow \mathrm{CO}+\mathrm{H}_{2} \mathrm{O}(3) & E^{0}=-0.76 \mathrm{~V} \\
\mathrm{CO}_{2}+4 \mathrm{e}^{-}+4 \mathrm{H}^{+} \rightarrow \mathrm{H}_{2} \mathrm{Co}+\mathrm{H}_{2} \mathrm{O}(4) & E^{0}=-0.72 \mathrm{~V} \\
\mathrm{CO}_{2}+6 \mathrm{e}^{-}+6 \mathrm{H}^{+} \rightarrow \mathrm{CH}_{3} \mathrm{OH}+\mathrm{H}_{2} \mathrm{O}(5) E^{0}=-0.62 \mathrm{~V} \\
\mathrm{CO}_{2}+8 \mathrm{e}^{-}+8 \mathrm{H}^{+} \rightarrow \mathrm{CO}_{4}+2 \mathrm{H}_{2} \mathrm{O}(6) & E^{0}=-0.48 \mathrm{~V}
\end{array}
$$

金属錯体を（2）-(6) 式の反応の触媒として用いる際には, その酸化還元電位が, それぞれの反応の平衡電位よりも負側 にあることが必要条件となる. 興味あることに, 各反応の平 衡電位と電子数に関しては, シュウ酸生成を除いて直線的な 相関が見られる (Fig.1)。ここで，もし金属錯体上で $\mathrm{CO}_{2}$ が，スキーム 1 に従って還元され，各中間体の金属一炭素結 合の開裂で 2-6 式の反応が起こると仮定すると, Fig. 1 は プロトン性の溶媒中では $\mathrm{M}-\mathrm{C}(\mathrm{O}) \mathrm{OH}>\mathrm{M}-\mathrm{CO}>\mathrm{M}-\mathrm{C}(\mathrm{O}) \mathrm{H}$ $>\mathrm{M}-\mathrm{CH}_{2} \mathrm{OH}>\mathrm{M}-\mathrm{CH}_{3}$ の順序で金属一炭素結合が切断され やすくなることを示唆しているように思われる. 一方，直線 関係から大きくずれているシュウ酸生成の律速過程は（2）(6) 式の $\mathrm{CO}_{2}$ 還元反応とはかなり異なっていることを示し ている.

\section{3 金属錯体上での $\mathrm{CO}_{2} / \mathrm{CO}$ 変換}

ルイス酸としての二酸化炭素は自発的に炭素原子で塩基サ イトに結合するが，塩基点が遷移金属と非遷移金属で全く異 なった反応性を示すにたとえば， $\mathrm{d} z^{2}$ 軌道に電子を有する 5 配位の遷移金属錯体は $\mathrm{CO}_{2}$ 気流下では $\mathrm{M}-\eta^{1}-\mathrm{CO}_{2}$ 錯体を形 